\title{
Social media and the reading culture revolution among digital natives
}

\author{
Dahlia Dahlan ${ }^{\mathrm{a}, 1, *}$ \\ ${ }^{a}$ Communication Study Program Universitas Muhammadiyah Buton, Jl. Betoambari, Lanto, Batupoar, Kota Bau-Bau, Sulawesi Tenggara 93724 \\ ${ }^{1}$ dahliadahlanikom@gmail.com* \\ * corresponding author
}

Article history

Received 09-10-2021

Revised 10-11-2021

Accepted 11-11-2021

\section{Keywords}

Reading culture revolution

New Media

Digital Naratuves

Patterns Media Consumption

Introduction

\begin{abstract}
Reading is one of the intellectual activities that only humans have that develops along with the writing system. The culture of reading does not just grow, because human history records the development of the writing system through a very long journey. The study, which involved 41 respondents aged 17-21 years who were randomly selected, showed a shift in the reading culture from print media to online media, related to reading patterns, gender aspects, reading frequency, and duration. From a gender aspect. The shift in the reading culture among young people is also greatly influenced by the characteristics of online media that print media lacks. The practicality and mobility of online media as well as easy access are some of the advantages that attract young media users. Books, newspapers/tabloids, and magazines do not have this characteristic. required Greater effort is more expensive to access print media which is incompatible with the characteristics of the digital natives. Although it has a number of advantages, online media is still considered to have a number of weaknesses compared to print media. One of the weaknesses of online media is the inaccuracy of the information, because the writing often does not apply the principle of cross-checking and confirmation, and contains more subjective opinions. The survey results reinforce the tendency of new media audiences to be not merely positioned as objects that are the target of messages. The tendency to change in reading culture is closely related to audiences and changes in media technology and the meaning of media have renewed the role of audiences to become more interactive with messages, and new media consumers who are dominated by young people can determine how to access according to their wants and needs.
\end{abstract}

This is an open access article under the CC-BY-SA license.

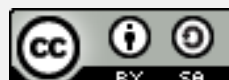

\section{Introduction}

Historians estimate that humans began to recognize writing and reading culture around 3000 years ago when Mesopotamians in the Middle East began to develop a writing system (http://en.wikipedia.org/wiki/ History_of_writing). Since then, there has been a shift from the oral tradition to the written tradition in line with the increasing need for the human ability to record data and information related to trading and agricultural activities (Gilfillan \& Xidias, 2017).

The human ability to create and understand written symbols and symbols is developing along with the development of civilization. The written tradition is increasingly shifting the oral tradition when various inventions in the field of printing make it easier to reproduce messages in writing. Two of the milestones of the discovery were marked by the development of the manual printing press by Johannes Gutenberg in 1450, which is called the "early modern" period (lasting from 1450 to 1789). Along with the development of printing technology, especially during the steam engine 
during the Industrial Revolution Era, since then the public has become easier to access information because printed materials such as books can be mass-produced.

\section{Theorotocal Framework}

a. New Media

Communication requires the media to convey messages from communicators to communicants. The development of information and communication technology led to the emergence of new media. New media is a term used for all forms of mass communication media based on communication technology and information technology. The new media that has these characteristics is the internet (Boyd \& Vivian, 2019).

Media - according Bonghi \& Trainotti (2006) is a term that includes various cultural media products that can be grouped into two types, namely traditional media and new media. Traditional media, which have evolved from the nineteenth to the twentieth centuries, refer to the types of media produced by a handful of producers that communicate with large audiences. Therefore, with its characteristics, traditional media is often called one-many-many media.

Unlike traditional media, new media began to be developed at the end of the twentieth century and continued to be refined in the twenty-first century. The characteristic of new media is that it is computer-based with more complex interaction patterns between producers and consumers of media, so it is often called many-to-many media.

Terry Flew in the book "New Media: An Introduction" Mangold \& Faulds (2009) emphasizes new media as digital media, namely all forms of media that combine and integrate data, text, sound, and images stored in digital format. In addition, the new media is distributed rapidly via fiber optic, cable, satellite, and transmission systems based networks microwave.

Furthermore, Martin Lister, et al in the book "New Media: A Critical Introduction" (Bakić-Mirić, 2018) explain that new media can be seen from the following:

1) Forms of new experiences in text, entertainment, fun, and patterns of media consumption (computer games, simulations, special effects films).

2) New ways of presenting the world, using media that offer new representational possibilities.

3) Form a new relationship between users, consumers, and media technology.

4) Forms of new experiences from self-identity and community in interacting.

5) A new conception of the biological relationship between human beings and media technology.

Dekker (2003) describes five main categories of new media which are differentiated based on the type of use, content, and context, namely:

a) Interpersonal Communication Media, including telephone and electronic mail. In general, content is personal and easy to remove and the relationships that are created and strengthened are more important than the information conveyed.

b) Interactive Game Media, including computer and video games, plus virtual reality equipment. The main innovation lies in interactivity and the dominance of process satisfaction over-usage.

c) Information Search Media, which is a very broad category but the internet /WWW is an important example and is considered as a library and data source whose size, actuality, and accessibility have never existed before.

d) Collective Participatory Media, as a special categoryincludes the use of the internet to share and exchange information, ideas and experiences, as well as to develop active personal relationships, for example, social networking sites.

e) Broadcasting Media Substitution, where the main reference is the use of media to receive or download content that in the past was usually broadcast or disseminated by other similar methods, such as watching films and television programs or listening to radio and music.

One of the new media that is now developing is the mobile telephone or better known as Cellular phones, where there is increasing use of it among teenagers. Cellular phones, citing Rich Ling's research, have a specific function for adolescent users. Besides functioning as a means of communication, a means of coordinating their lives, it also facilitates their social interactions. Ling 
further explained cell phones for adolescents are defined specifically as a symbol of maturity (symbol for adolescents) in the context of interactions with others (Widrow et al., 1975).

b. Media Social

As global Internet users increase, which is approaching 3 billion, Web 2.0 appears, which is marked by the proliferation of the phenomenon blogging in cyberspace, namely the presence of personal websites - which are then called blogs. The term blog, which stands for weblog, was first used by Jorn Barger in 1997. The era of Web 2.0 marked the birth of an era of interactivity when Internet users were no longer passive users but active users. Internet users are now able to update data continuously and quickly and are also able to provide their own comments (Watie, 2016).

In general, the characteristics of the internet as an online media - especially in the era of Web 2.0 are the interactivity, hypertextuality, multimedia nature, and personalization of digital content. New media that apply Web 2.0 technology is very supportive of media development so that many old media are transforming into new media. Web 2.0 technology was first coined by Tim O'Reilly in 2003. Web 2.0 technology has the concept of interaction and sharing between users. The characteristics of Web 2.0 according to O'Reilly, namely:

(a) Web as a platform for running any application

(b) The Web is able to collect knowledge into a very broad unit

(c) The more complete and strong the data, the more successful the site will be

(d) Can be continuously updated without the need for a long time

(e) Make it easier for users to create new services with existing services

(f) Applications in Web 2.0 can be used through various devices

(g) Web 2.0 applications can connect many users

Marking the presence of the Web 2.0 era encouraging the birth of various forms of social media (social media) such as Friendster, MySpace, Facebook, Linkedin, Twitter, Path, YouTube, Instagram, and many more. The presence of social media did not appear only but began with the birth of the social networking site SixDegrees.com in 1997. Through this innovative site, internet users can go online simultaneously which is followed by the formation of general principles that shape the characteristics of social media, namely: (1) User profiles, a feature that contains user data provided for friendship sites; (2) List of Friends, a feature containing a list of friends connected to the user; (3) Share Friends with others, a feature that allows users to interact with other parties who have similar interests or backgrounds (Irawan et al., 2020).

Even though it only lasted less than 3 years, SixDegrees.com - for a number of reasons such as users feeling uncomfortable providing information about themselves online and interacting with strangers. Not to mention the reason people were not used to and needed social networking sites at that time. However, it must be admitted that the existence of SixDegrees has laid an important foundation for social media in the future.

The term social media refers to the use oftechnologiesweb-based and mobile, namely all gadget devices, which are characterized by interactive forms of communication. Andreas Kaplan and Michael Haenlein define social media as a collection of(internet-based applications internet-based applications) built on the ideological foundation and technology of Web 2.0. which enables the creation and exchange of content. In short, social media is a medium for social interaction, as a set of ways to enrich social communication using accessible and broad communication techniques (APJII, 2019).

Koemans, van Vroenhoven, Karreman, \& Bekker (2015) - in an article entitled The History of Social Media - defines social media as a general term to describe various activities that integrate technology, social interaction, and the production of words, images, video, and audio. Further explained, this social interaction and the way information is presented depends on various perspectives and "buildings" which are interpreted together, as humans share stories and understandings .

W: http://journal2.uad.ac.id/index.php/commicast/index |E: commicast@comm.uad.ac.id 


\section{c. The Rise of Social Media vs Mass}

Media Social media takes a variety of forms, something that is lacking in mainstream media. The form of social media consists of forums on the internet, weblogs, social blogs, microblogging, wikis, podcasts, photo or image services, videos, to social bookmarking. Kaplan and Haenlein ( in Khomsahrial, 2016) divide social media into six forms, namely: (a)Collaborative projects (eg Wikipedia); (b) Blogs and microblogs (for example, Twitter); (c) Content communities (eg Youtube); (d) Social networking sites (for example, Facebook); (e) Virtual game worlds (eg World of Warcraft); (f)Virtual social worlds (for example, Second Life).

Meanwhile, Stephanie Miler in an article entitled Is Social Media Synonymous with Social Networking? classifying variants of social media, into six forms, namely: (a) Blog, containing a collection of articles that can be commented on by the community; (b) Forums, featuring specific topics discussed; (c) Content communities, in the form of media that enable various content, (stories, images, photos, videos, and links) (for example YouTube); (d) Wiki, containing documents and databases created and edited by the community (eg Wikipedia); (e) In virtual worlds, the user enters and builds a virtual life in a virtual world (eg Second Life). (f) News aggregators, featuring multiple sources of information from a single site (for example Netvibes). (g) Microblogging, containing short messages (for example Twitter).

Unlike traditional media (mainstream media), social media has several special characteristics including: (1) Reach -Reach of social media from small scale to global audiences. In addition, social media has the characteristics of being more decentralized, less hierarchical, and differentiated by differences in production and usage systems (multiple points of production and utility.). (2) Accessibility (Accessibility)- Social media more accessible to the public at an affordable cost. (3) The use of (Usability)- Social media is relatively easy to use because of member-Lukan special skills and training. (4) Actuality (Immediacy) - Social media can provoke a faster audience response. (5) Fixed (Permanence) - Social media can replace comments instantly or easily do the editing process.

Web 2.0, according to Reilly, allows internet users to become producers in the form of ideas, text, videos, images, and not just consumers (user-generated content). The difference is in stark contrast with Web 1.0 technology which places users as consumers (Khairiah, 2020). So, is there a difference in the paradigm between social media and mass media or is it often called mainstream media? According to Ben Edwards, Director of New Media Communications at IBM, there are quite basic paradigm differences between social media and traditional mass media. Edwards distinguishes it based on 7 indicators so that it appears the peculiarities of the paradigm between the two media (Edwards, 2013).

The seven indicators used consist of: (1) Producers (Publisher); (2) Level of efficiency (Economics); (3) Users / Audiences (Audience); (4)Engagement; (5) Response (Voice); (6) Communication(Communications);(7) Marketing(Marketing), as shown in Table I.

Table 1. differences paradigm of social media and mass media

\begin{tabular}{|c|c|c|}
\hline & Mass Media & Social Media \\
\hline Publisher & Professional publishing & Self-publishing \\
\hline Economics & High cost & Low cost \\
\hline Audience & Mass & Niche \\
\hline Engagement & Passive & Active \\
\hline Voice & Institutional & Individual \\
\hline Communication & Publisher & Enabler \\
\hline Marketing & Advertising & Publishing \\
\hline
\end{tabular}

Fig. 1. Source: Edwards 2013.

With the characteristics of online media - especially social media - it is slowly starting to shift the role of mainstream media. Especially when it is related to the current demographic aspect when the number of digital natives (a term for digital-literate young people) is increasingly dominant compared to digital migrants who are "forced" into digital culture. The use of online media and social media shows an increasing trend. 


\section{Method}

This research uses a quantitative descriptive approach because it aims to get a more accurate picture of changes in the culture of consuming media, especially reading culture among adolescents or fall into the category of the digital native. The total population of 1,613 people, the study involved 41 respondents who came from Communication Science Study Program students, Faculty of Communication and Business, Telkom University, Bandung. Respondent profiles based on gender are as follows, namely 11 people (27\%) male and 30 (73\%) female (see Table 3).

Table 2. Profile of respondents by gender

\begin{tabular}{|c|c|c|c|}
\hline No & Gender & f & \% \\
\hline 1 & Male & 11 & 27 \\
\hline 2 & Female & 30 & 73 \\
\hline \multicolumn{2}{|c|}{ TOTAL } & 41 & 100 \\
\hline
\end{tabular}

Fig. 2. Source: Research Results

\section{Results and Discussion}

After the text edit has been completed, the paper is ready for the template. Duplicate the template file by using the Save As command, and use the naming convention prescribed by your conference for the name of your paper. In this newly created file, highlight all of the contents and import your prepared text file. You are now ready to style your paper; use the scroll down window on the left of the MS Word Formatting toolbar.

\section{Conclusion}

Research that took place in September 2014 produced a number of results, including a description of the respondent's profile based on age category. The respondents in the study came from the age range of 17-21 years, where the number of respondents aged 21 years was 16 people (39\%), followed by respectively 8 respondents aged 20 years and 18 years $(20 \%)$, and the last was 17 years old $(12 \%)$.

Judging from the reading sources used by the respondents, there is an interesting phenomenon when 38 respondents (93\%) still read books, followed by 27 respondents (66\%) still reading newspapers/tabloids, 27 respondents $(66 \%)$ reading magazines, and 41 respondents ( $100 \%$ ) read online media (Table 3 ).

Table 3. profile of respondents based on reading sources

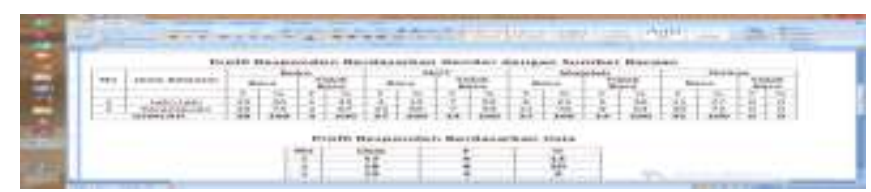

Fig. 3. Source: Survey Results (2014)

Of the types of books most read, $28(68 \%)$ of respondents chose to read fiction books, 8 respondents (20\%) read textbooks/lecture texts, and 5 respondents (12\%) chose nonfiction books.

Respondents have various ways to obtain printed reading material (books, newspapers/tabloids, and magazines). For the book category, 21 respondents (51\%) chose to borrow, 17 respondents (41\%) chose to borrow, while 3 respondents $(8 \%)$ chose to get books for free or were given by other parties.

In consuming book reading material, there are differences in the frequency of reading the book (in one day), the duration of reading the book, and the location for reading the book. For the 
frequency of reading books, there were 34 respondents (83\%) with a habit of reading books 1-2 times per day, only 4 respondents (10\%) had a frequency of reading 3-4 times/day, and the remaining 3 respondents (7\%) had a habit of reading books. read a book more than 4 times/day.

Reading habits are also related to the duration or duration of reading books, namely 25 respondents $(61 \%), 11$ respondents $(27 \%)$, and 5 respondents (12\%). Another factor related to the habit of reading books is the location where, 40 respondents ( $98 \%$ ) often read at home (or boarding houses), while the remaining 1 respondent (2\%) reads books on campus.

The habit of reading newspapers or tabloids includes the type of reading, duration, frequency, reading time, and location of reading newspapers/tabloids. Newspapers / tabloids in the Lifestyle (lifestyle) category were chosen by 46 percent of respondents, following the general newspapers / tabloids (21\%), Infotainment newspapers / tabloids (13\%), Sports newspapers / tabloids (8\%), Political newspapers / tabloids (8\%) ), and automotive newspapers / tabloids (4\%).

While the length of reading or the duration of reading newspapers/tabloids each 88 percent of respondents spent less than 30 minutes, the rest (12\%) read between 30 to 60 minutes in one day. In terms of time spent reading, 33 percent of respondents chose to read newspapers/tabloids in the morning, 29 percent of respondents at night, 21 percent during the day, and 17 percent read in the evening.

Another case with the habit of reading magazines is seen from the frequency, duration, method of obtaining, and the type of magazine read. There is 93 percent of respondents reading magazines 1-2 times a week, while 7 percent read magazines 3-4 times a week. The duration used to read the magazine from 66 percent of respondents is less than 30 minutes, while 31 percent of respondents spend 30-60 minutes, and only 3 percent spend more than 60 minutes reading the magazine.

This research shows that 100 respondents read online media with varying frequency and duration. There is 41 percent of respondents have used online media for less than five years, while 41 percent have used online media for 5-10 years. The rest, 18 percent, claimed to have used online media more than 15 years ago.

Respondents claim to have a much longer duration reading online media than printed books, newspapers/tabloids, and magazines. There is 51 percent of respondents using online media for more than 60 minutes every day, while 37 percent of respondents use online media for 30-60 minutes, the remaining 12 percent of respondents use online media for less than 30 minutes (see Table 4).

Table 4. Reading duration based on reading sources/media

\begin{tabular}{|c|c|c|c|c|c|c|c|c|c|}
\hline \multirow{2}{*}{ No } & \multirow{2}{*}{ Duration of } & \multicolumn{2}{|c|}{ Books } & \multicolumn{2}{c|}{ Newspapers / Tabloids } & \multicolumn{2}{c|}{ Magazines } & \multicolumn{2}{c|}{ Online Media } \\
\cline { 3 - 10 } & & $\boldsymbol{F}$ & $\boldsymbol{\%}$ & $\boldsymbol{F}$ & $\boldsymbol{\%}$ & $\boldsymbol{F}$ & $\boldsymbol{\%}$ & $\boldsymbol{F}$ & $\boldsymbol{\%}$ \\
\hline 1 & $>30$ minutes & 11 & 27 & 21 & 88 & 19 & 66 & 5 & 12 \\
\hline 2 & $30-60$ minutes & 25 & 61 & 3 & 12 & 9 & 31 & 15 & 37 \\
\hline $3>$ & 60 min & 5 & 12 & 0 & 0 & 1 & 3 & 21 & 51 \\
\hline \multicolumn{2}{|r}{ Total } & 41 & 100 & 24 & 100 & 29 & 100 & 41 & 100 \\
\hline
\end{tabular}

Fig. 4. Source: Survey Results (2014)

Time used to consume books the majority of the evening (61\%), while newspaper/tabloid magazines are more spread from the morning, afternoon, evening, and night. Meanwhile, online media is mostly used at night (76\%).

Meanwhile, the average duration in one day that respondents use to consume online media is quite scattered. There is 39 percent of respondents using online media between 3-6 hours a day, 32 percent of respondents using 1-3 hours a day, 20 percent of respondents using between 6-9 hours a day, and 9 percent who use online media more than 9 hours a day.

The methods used to access online media from the respondents are also different, although more than half of 68 percent of respondents use smartphones or smartphones, 17 percent use laptops as gadgets to access media online, while 15 percent of them still use laptops. Of the forty-one 
respondents surveyed, all use Google (100\%) as a search engine (search engine) when performing searches in cyberspace.

The use of online media by respondents is more to fulfill entertainment functions (49\%), information (44\%), 7 percent of respondents use online media for security functions, and no one uses it for educational functions. The results of the research also succeeded in exploring the type of content sought by respondents, the majority of whom were looking for entertainment andcontent infotainment (56\%), news (37\%), science and technology (5\%), and online shopping (2\%).

The activities of the respondents when using online media can be described as follows, namely most (46\%) searched the Internet, the rest were chattingchatting or(44\%), sending electronic mail (7\%), and online games (3\%). Theactivity of chatting the respondents is mostly used through theapplication instant messaging Line (76\%), Wechat (7\%), Whatsapp (5\%), and other applications $(12 \%)$.

The type of online media most frequently accessed by respondents is social media (66\%), followed by websites (32\%), and finally blogs $(2 \%)$. Twitter is the most used social media for respondents (34\%), followed by Facebook (22\%), Path (20\%), Instagram (12\%), and Youtube $(10 \%)$.

A more basic issue regarding the change in the culture of reading from printed media, either through newspapers / tabloids, and magazines, the respondents who were surveyed had a number of reasons. The author proposes 10 criteria that are owned by online media which are relatively different from the characteristics of print media. Of the ten criteria, more than half of respondents $(58 \%)$ chose online media because it is more practical than print media. Followed by considerations of easy access (20\%), accuracy of information, speed, completeness of information, and easy to adjust to needs (5\% each). Finally, the characteristics of online media being cheaper than print media were considered by respondents (2\%). None of the respondents answered that the characteristics of information depth, visual appeal, and the message were easy to understand as the advantages of online media characteristics compared to print media.

On the other hand, online media is considered to have a number of shortcomings compared to print media. There are 44 percent of respondents who think online media is inaccurate. Then the respondents surveyed thought that the information contained in online media was not in depth $(15 \%)$, accessing online media was more expensive (12\%), difficult to access (10\%), slow (10\%), difficult to adjust to user needs (5\%) ), information is incomplete (2\%), and impractical (2\%).

\section{Acknowledgment}

I am deeply indebted to my supervisor, Mr. Harry Fajar Maulana, From Department of Communication Sciences Study, for warm support, inspiration and thoughtful guidance.

\section{References}

APJII. (2019). Survei APJII: 49\% Pengguna Internet Pernah Dirisak di Medsos. Apjii, April.

Bakić-Mirić, N. (2018). Social Media: A Critical Introduction. European Journal of Communication. https://doi.org/10.1177/0267323117753746

Bonghi, C., \& Trainotti, L. (2006). Stewart Postharvest Review. Gene Expression.

Boyd, P., \& Vivian, C. (2019). Should we fertilize oceans or seed clouds? No one knows. In Nature. https://doi.org/10.1038/d41586-019-01790-7

Dekker, P. (2003). Meanwhile, Within the Frege Boundary. Linguistics and Philosophy. https://doi.org/10.1023/A:1025896723582

Edwards, W. (2013). Conservatism in human information processing. In Judgment under Uncertainty. https://doi.org/10.1017/cbo9780511809477.026 
Gilfillan, S., \& Xidias, J. (2017). We now know: Rethinking Cold War history. In We Now Know: Rethinking Cold War History. https://doi.org/10.4324/9781912281442

Irawan, A. W., Yusufianto, A., Agustina, D., \& Dean, R. (2020). Laporan Survei Internet APJII. In Laporan Survei Internet APJII.

Khairiah, M. (2020). Louiz Zamperini's American Dreams as Reflected in the Film Unbroken. Commicast, 1(2), 33. https://doi.org/10.12928/commicast.v1i2.2727

Khomsahrial, R. (2016). Kom Dan Realitas Sosial. Ilmu Komunikasi.

Koemans, R. G., van Vroenhoven, S., Karreman, A., \& Bekker, M. H. J. (2015). Attachment and Autonomy Problems in Adults With ADHD. Journal of Attention Disorders. https://doi.org/10.1177/1087054712453170

Mangold, W. G., \& Faulds, D. J. (2009). Social media: The new hybrid element of the promotion mix. Business Horizons. https://doi.org/10.1016/j.bushor.2009.03.002

Watie, E. D. S. (2016). Komunikasi dan Media Sosial (Communications and Social Media). Jurnal The Messenger. https://doi.org/10.26623/themessenger.v3i2.270

Widrow, B., Williams, C. S., Glover, J. R., McCool, J. M., Hearn, R. H., Zeidler, J. R., Kaunitz, J., Dong, E., \& Goodlin, R. C. (1975). Adaptive Noise Cancelling: Principles and Applications. Proceedings of the IEEE. https://doi.org/10.1109/PROC.1975.10036 